\title{
HIV Testing Among "MSM": Prevention Technologies, Sexual Moralities and Serologic Self-surveillance
}

\author{
| ${ }^{1}$ Claudia Mora, ${ }^{2}$ Mauro Brigeiro, ${ }^{3}$ Simone Monteiro |
}

Abstract: Global AIDS guidelines have prioritized the expansion of HIV testing among the groups most exposed to the virus, such as those referred to as men who have sex with men (MSM). This paper analyses the relationships between the production of prevention strategies and sexual moralities based on the results of a systematic review of academic literature about testing with gays and MSM (2005-2015, using the PubMed, Sociological Abstract and Lilacs databases). The analysis of 65 articles reveals the recruitment strategies for identifying target-subjects and how they are held responsible for their serological self-surveillance, including routine tests. The findings also point to a diversification of testing locations. Implicit assumptions about sexuality and gay affection are conveyed through the interventions' emphasis on sociability spaces and occasional sex, especially when facilitated by the use of apps. Attentive to the symbolic dimensions of the new prevention technologies and strategies, we argue that the expansion of testing with a focus on "MSM" signals a displacement of health interventions. If before actions to control the epidemic sought to intervene in sexual practices, the current efforts are concentrated on promoting self-surveillance of one's serological status.

> Keywords: testing; HIV; homosexuality; risk; sexual moralities.

\footnotetext{
${ }^{1}$ Institute of Social Medicine, Rio de Janeiro State University. Rio de Janeiro-RJ, Brazil. (claudiamoraca@hotmail.com). ORCID: 0000-0003-4854-3429

${ }^{2}$ Laboratory of Environmental Education and Health, Oswaldo Cruz Foundation. Rio de JaneiroRJ, Brazil. (maurobrigeiro@ hotmail.com). ORCID: 0000-0002-0791-1670

${ }^{3}$ Laboratory of Environmental Education and Health, Oswaldo Cruz Foundation. Rio de JaneiroRJ, Brazil. (monteiro.simone. fiocruz@gmail.com). ORCID: 0000.0003.2009.1790
}

Received: 26/11/2017 Approved: 15/02/2018 Revised: 10/04/2018 


\section{Introduction}

In the beginning of the 1980 s, the association of the first AIDS cases among gays identified with a risky sexual 'lifestyle' led to the resurgence of stigmas linked to homosexuality. The responses confronting the emergence of a new and fatal condition, with a significant moral weight, illustrate how government and social society actions were infused with discursive constructions and disputes of signification surrounding the people affected (TREICHLER, 1987). In particular, the official responses for gay men were late and controversial, including messages of isolation or blaming the sick. These actions appeared to mirror dominant representations of sexuality that distinguished between "bad sex" (homosexual, promiscuous, commercial) and "good sex" (monogamous, reproductive, non-commercial) (RUBIN, 1998).

In the 1980s, the media and scientific narratives about AIDS expressed ethnocentric conceptions with sexist and homophobic overtones. The hypothesis of an African origin of the epidemic predominated, but the possibility of recognizing that the exportation of blood products from the United States might have disseminated the virus in other places was rejected (TREICHLER, 1987). The production of "discursive dichotomies" was significant, such as delineating lines between the categories of "MSM" and the "general population", generating imaginary borders between people exposed and protected. Despite recognizing transmission via heterosexual relationships, these representations reverberated socially, establishing a moral boundary between the 'victims' and the 'responsible/ guilty' for the infection (KNAUTH, 1997).

In the decades that followed, there were diverse disputes and transformations in the discursive constructions surrounding 'homosexualized representations of AIDS'. The outcome of creative and globalized activism, spearheaded at the time by the North American gay movement, condom use and "safe sex" took off as prevention strategies coined by the AIDS social movement (EPSTEIN, 1996). In addition, following the changes in the technical and political frameworks for confronting the epidemic, the categories referring to target-groups were redefined. The terms risk groups and risk behaviors, which are outcomes of the 1990s epidemiological discourses, were transformed to groups vulnerable to HIV that focused on social determinants as the highest susceptibility to HIV infection (AYRES et al., 2007). 
In short, throughout the history of AIDS, the critical reflection of community organizations and academic sectors had an important role in questioning the actors and practices involved in this process (KIPPAX et al., 2013; AGGLETON; PARKER, 2015), as well as the debates about stigma associated with the disease and the sexuality of people affected by the epidemic (MONTEIRO et al., 2013).

In the current global AIDS prevention guidelines (UNAIDS, 2014), the term groups most vulnerable to $H I V$ was substituted with 'key-populations'. Thus, in the context of a "concentrated" epidemic, the prevention and care agendas and technological innovations have prioritized the populations with the highest prevalence rates, invariably MSM, the incarcerated population, injecting drug users, sex workers, transgender persons, adolescents, and young people (WORLD HEALTH ORGANIZATION, 2014). These guidelines indicate a new framework for prevention based on research and biotechnologies developed to reduce new infections (male circumcision, pre-exposition prophylaxis, treatment as prevention, etc.) (MONTEIRO et al., 2017; SEGURADO, 2013). It is necessary to observe the production of these technologies as a social process, as they are molded to each discovery or technological advance and put into practice through ideologies, values and moralities.

Camargo Jr et al. (2013) argue that the production of scientific evidence and its consolidation in public policies are crosscut by axiological and epistemological factors (facts and values). The authors seek to understand the ideologies, assumptions and world visions of the rhetoric that specialists use to sustain the topic of male circumcision as an alternative to HIV prevention. Through these analyses, their research contributes to debates surrounding the technical, ethical and sociocultural reputability of health interventions. A study conduced by Montgomery (2012) about feminine microbicide clinical trials, also inspired by a critical gaze of scientific production processes, reveals how the production of HIV prevention technologies are traversed by heteronormative and colonial visions. Their analysis demonstrates how these same visions are expressed through the idealization of patients, their sexual practices, and their gender constructions.

In the new HIV prevention milestones defined by the 90-90-90 guidelines (WORLD HEALTH ORGANIZATION, 2014) - focused on the identification of people infected, taking their treatment and reducing their viral loads -, testing has earned a particular importance. In this sense, the identification of people infected 
currently occupies a central role in reaching the international goals for the AIDS response, which has resulted in shifts in the uses and meanings of the diagnosis (MONTEIRO et al., 2017).

In addition to the recent emphasis on the identification of positive cases under the motto "Test and treat", it is worth highlighting the processes through which testing has expanded over the last decade, such as the progressive introduction of the test in distinct contexts, like emergency rooms, mobile units and public spaces (FONNER et al., 2012, MORA et al., 2014). Within this context, the mechanisms through which public health strategies seek to integrate themselves into homosexual experiences can also be observed, be it through offering focalized testing and prevention biotechnologies, like the self-test, or communication technologies (such as information sites and relationship apps).

Tendencies in expanding testing, in addition to the focus on 'key populations', involve a discursive production about the sexuality of these interventions' targetsubjects. Considering that the current guidelines focus on the population referred to as "MSM", in this article we seek to identify how homosexual sociability and sexuality are expressed in the testing technologies and strategies studied within the specialized literature. We start from the assumption that academic production constitutes a source of sociological analysis. Our objective is to examine the relationship between prevention strategies and sexual moralities based on a literature review over the period of 2005-2015 about the meanings of testing offers, testing recruitment strategies, and justifications for the expansion of testing among "gays and MSM".

\section{Methods}

We followed the required steps for a systematic review: the choice of the database, identification of the search terms, definition of the inclusion and exclusion criteria, classification and analysis of the selected articles by (at least) two researchers in a blinded fashion (PAI et al., 2004). The database and bibliographic websites were chosen due to their coverage of the international literature in the area of Public/ Collective Health and Social and Human Sciences in Health. The searches included articles in English, Spanish and Portuguese published in the databases Pubmed, Sociological Abstract, Lilacs, Cochrane Systematic Reviews and Scielo from 2005 to July 2015. 
The search terms were defined from MeSH (Medical Subject Headings) and DeCS (acronym in Portuguese - Health Sciences Descriptors), but were not restricted to terms indexed in these systems. The searches consisted in a combination of search terms relative to testing and MSM, that included: testing, counseling, testing strategies, testing methods, mobile HIV testing, mobile testing, mobile unit, treatment as prevention, combination HIV prevention, HIV prevention, HIV prevention strategies, Point of Care, home-based, self-testing, community-based, community mobilization; MSM, homosexual, bisexual, gay.

The reference selection followed the following inclusion criteria: voluntary test in different locations; use of a diagnostic test; test recruitment strategies; effects of the test and counseling; prevention linked to the test; cost-benefit analysis; evaluation; the effects of stigma on testing services. The exclusion criteria included studies about laboratory techniques or other infectious diseases (not sexually transmitted) and analyses that did not address testing access or frequency.

The search generated 167 abstracts. After excluding those present in more than one database, 133 abstracts remained and were stored in the reference manager Mendeley. After reading the abstracts, they were classified according to: methodology, country, testing barriers, predictive factors for seeking out the test; test strategies and methods; implications of the test-diagnosis. Given our aim to understand the relationship between prevention technologies and sexual moralities, we selected articles about test recruitment and offering strategies for MSM, which included a total of $\mathbf{6 5}$ references, listed in Table 1.

In terms our focus on the relationship between prevention and sexuality, the analysis included two axes that will be discussed in the results. The first is the identification and designation of target-subjects for recruitment strategies and a new form of involving them in prevention through initiation into serological surveillance. The second addresses the diversification of testing spaces and the way in which sexuality, affect and gay sociability have become implicit in the prevention discourse.

\section{Results and discussion ${ }^{1}$}

\section{The target-subjects of recruitment strategies: "MSM" as a naturalized category and the responsibilization of serological surveillance}

Studies in the Social Sciences and Health fields have argued that the use of categories to designate practices and sexual identities has not been sufficiently 
problematized in biomedical research about HIV/AIDS (PARKER et al., 2016; BOELLSTORFF, 2011; FORD, 2006; YOUNG; MEYER, 2005). These criticisms are based on the situational aspect of how individuals use sexual identities, their variations throughout life (and according to generational and class markers), in addition to the lack of correspondence between attraction, identity, and sexual practices (FRY, 1982; HEILBORN, 1996, 2004; FOLLER; MONTEIRO, 2012). These debates have problematized the naturalization of constructed and reified categories according to the logic of specialists. In the case of the acronym "MSM", Pecheny (2012) emphasizes its inadvertent use and the heterogeneity of meanings that each letter could represent depending on who uses it; for example, what could be considered as "sex" (type of practice and frequency). The 65 articles in this review corroborate this observation. Rarely is it made explicit if participants were classified based on self-classification of their identity, or if the researchers used behavioral criteria (ex.: partner type, type and frequency of practices).

We noted that the literature uses different criteria when classification is based on sexual practices. In a survey about cases of non-identified infections conducted in homosexual sociability locations in the United States, ${ }^{2}$ the categorization MSM was applied to those that referred to at least one sexual relationship with a man in the last year. In another study about access to MSM among people who frequent saunas, parks and bars in Bangkok, ${ }^{3}$ the criteria was reporting oral or anal sex with men in the last six months.

Of the 65 articles, 53 use the term MSM in the title, while only 12 privilege the terms "gay" or "bisexual". ${ }^{4}$ The use of the acronym could be related to the authors' interest in including men with homosexual practices who do not identify as gay, a reason why some of the studies make a distinction (at least semantically) in their texts between gays, bi and "other MSM". Some publications reveal that the types of strategies chosen are linked to determinant identity molds, affective relationship forms or gay sociability. For example, they mention "gay couples-based services", "gay venue" and "gay friendly Voluntary Counseling and Testing".

The predominant use of the MSM acronym in the reviewed literature appears to be related to the fact that the majority of the articles are quantitative, consistent with the term's history of being promoted as a category within epidemiology. In the 1990s, the MSM category was a way to group men that did not necessarily 
identify as gays, but reported sexual practices (not necessarily exclusive) with men into abstract categories (YOUNG; MEYER, 2005; PECHENY, 2012).

In some cases, the researchers report that sexual identity is defined according to self-classification, but it is not explicit if the categories are predefined by the study or referred to by the participants. The consequences of this imprecision are related to the erasure of the ample identity spectrum among those categorized as MSM, which results in inadequate generalizations (AGGLETON; PARKER, 2015).

We identified a concern in the literature with the level of surveillance and self-care in relation to HIV. The articles commonly describe measures of testing frequency, which is coherent with the topic studied. Nonetheless, it is worth noting how these studies and narratives of experiences use the sexual identity of study participants to interpret or explain higher or lower testing frequency. For example, it's common understanding that "MSM" who've never been tested don't do the test because they don't pertain to a "gay culture". In the same way, the analyzed literature explains that risk perception decreases the further away subjects are from the gay universe. ${ }^{5}$ In these articles, sexual identity (measured or designated) does not constitute data to understand sexual conduct; it turns into an explicative element for concerns about prevention and serological status.

In addition to the idea of risk perception, the acceptability of the test is studied in relationship to people's sexual identity. We cite an example. A survey with users of a mobile HIV testing unit in Spain ${ }^{6}$ included interviewees who had distinct sexual practices and were classified as MSM, MSW (men who just have sex with women) and women. The authors describe the higher acceptance of the test among MSM, interpreting it to be a result of a higher risk perception among this group. The other results, however, signal unprotected sex with a partner as being perceived of as the lowest risk, most frequent among women (41\%) and MSW (36\%); among MSM, it was $23 \%$. These data permit us to question the studies' premises and how they construct arguments about the behaviors of a sexual category/group and their higher or lower exposure to STIs/AIDS.

In the literature analyzed, common sociological concepts (such as "vulnerability") used to address the adverse conditions that increase exposure to HIV infection are used specifically to indicate barriers to accessing services and testing strategies. It's only within the frame of this concern that studies approach situations referring to stigma, homophobia and violence resulting from sexual discrimination. In 
these articles, the connections between experiences and HIV vulnerability are not discussed, especially in sexual-affective relationships. Stigma is highlighted primarily in terms of the obstacles it presents in accessing the test. ${ }^{7}$ According to this line of logic, such structural factors expose MSM to risks, making them more difficult to reach, especially in underdeveloped and developing countries. ${ }^{8}$

The literature also tends to approach structural questions, like AIDS stigma or healthcare coverage only in relationship to access to testing. ${ }^{9}$ The articles approach inequities in access to information about HIV diagnosis and treatment in this manner. Similarly, the literature treats sexual identity and discrimination from the point of view of its implications for public health strategies. They rarely reflect on the relationship between these topics and the conditions under which sexual interactions occur and people's vulnerability to infection. This aspect is especially evident in the way the studies problematize the non-revelation of sexual practices or the impossibility of identifying the participants' sexuality.

The routine offer of the HIV test is one topics covered in articles about testing strategies for people with homosexual practices. According to the new prevention model logic, testing permits the identification of people infected and the reduction of transmission through adequate medical treatment. Testing should be facilitated and stimulated. In this sense, offering the exam through diverse strategies is accompanied by the intense promotion of the importance and advantages of knowing one's HIV serological status. In diverse countries, like the United States, Canada and Australia, the periodic prescription of the HIV exam is part of a health service protocol promoted in the name of efficiency, especially for the groups most affected by AIDS. In Australia, for example, MSM's supposed periodic test seeking justifies a recommendation for testing and a clinic visit four times a year among MSM characterized as "high risk". ${ }^{10}$ In fact, the no revelation of sexuality in the context of clinical attention has become a problem in this context as it makes following protocol impossible for health care professionals. This entire apparatus of intense initiation and prescription of the test is what we call serological self-surveillance, which is promoted especially towards MSM.

In the review, we only found one study that problematizes the relationship between testing and coming out in the current scope of global AIDS policy. With a socio-anthropological approach, the article offers a stimulating discussion of the Chinese State's outsourcing of HIV testing to homosexual community organizations. 
The analysis demonstrates how recruiting subjects for testing through these means makes revealing MSM who traditionally would remain hidden in the official rates of heterosexual transmission possible. ${ }^{11}$

Some articles defend the expansion of testing by affirming that after diagnosis, there will be an increase in condom use, a reduction in partner numbers and treatment adherence, therefore reducing infection (even in situations of being exposed to the virus). ${ }^{12}$ It is under this optimistic logic that not testing has turned into a problem and testing a solution, suggesting testing as efficacious in terms of the "normalization" of sexual practices and self-care. ${ }^{13}$

In synthesis, recruitment strategies and the technologies for expanding testing depend on revealing a sexual identity. In the literature, there is a narrative that intersects the identity dimension with the offering of the diagnosis. This point is intertwined with the idea that these investments should involve making MSM responsible for their self-surveillance, as we will discuss below.

Despite the relevance of the epidemic's context in Latin America and the Caribbean where $30 \%$ of new infections occur among "gays and other MSM" (UNAIDS, 2016), the emphasis of the recruitment strategies can be read as privileging a social segment when compared to other groups that are also "targets" of AIDS responses in its fourth decade. With the aim of confirming the greater emphasis on the responsibilization for serological surveillance among MSM as compared to other 'key populations', we conducted an exploratory bibliographic search using the same methodology as our review, but including search terms related to sex workers and the trans population ("sex workers", "prostitution", "transgender", "transexual”).

According to the results, the proportion of articles about testing for male homosexuals $(\mathrm{N}=65)$ is three times higher than with sex workers $(\mathrm{N}=23)$ and almost 10 times as high as with the trans population $(\mathrm{N}=7)$. It is important to emphasize that articles about prostitution focus on female prostitution and that studies about MSM and prostitution were not identified. The literature about prostitution and the trans population is less expressive numerically and prioritizes prevention strategies that do not place testing as a central component. The testing actions for sex workers are characterized by strategies that promote health and highlight the importance of a right to autonomy and confidentiality ${ }^{14}$ through projects that recognize rights, citizenship and community mobilization ${ }^{15}$. In addition, they focus on strengthening social organizations and strategies to combat stigma and stimulate access to health 
services. ${ }^{16}$ The literature with a focus on the trans population is primarily in countries like Brazil, India and Thailand and about life conditions and the importance of integrated care. ${ }^{17}$

The largest offering of testing and technologies considered as innovative for recruiting MSM are marked by their emphasis on testing via the internet, relationship sites, apps, telephone, and OPT-IN (the continuous offer of testing in health services that only requires verbal or written consent). ${ }^{18}$ Concern about the possibilities of use and access (real or potential) of the self-test is also frequent. ${ }^{19}$ The strategies referred to as multi-component, prevention package, couples testing, condom and test social marketing, mobile testing units (in sociability spaces like saunas, clubs, plazas, etc.) also represent an important segment of actions referred to in the literature.

It is worth nothing that these health strategies do not apparently seek to control the sexual practices of MSM. However, by enthroning themselves in affective and social scenes, they seem to stimulate new elements of socio-sexual dynamics, such as the practice of serosorting (choosing partners based on their serological status). In addition, as we discuss in the following section, they seem to produce new classifications of MSM based on their relationship with the test.

\section{Sexual moralities deployed in approaches for testing recruitment strategies}

In our analysis of the literature we found that the previously mentioned testing technologies are validated or proven in sexual contexts considered to be typical of the homosexual universe. In the study descriptions and narratives of experiences, there are frequent references to the sexual interactions of those referred to as MSM. Casual sex is tacitly associated with arguments about the higher HIV incidence and prevalence rates within this group. Such assertions related to masculine homoeroticism are expressed though the characterization of men according to their sexual practices. In a unique way, differentiation in terms of their sexuality is only specifically mentioned when the people enrolled in the testing recruitment strategies are homosexual couples, or when the technologies are integrated into spaces like saunas or electronic relationship apps.

Testing initiatives for gay couples are an example of this differentiated concern regarding the sexuality of those referred to as MSM. They highlight how infection in these cases occurs in the context of affective relationships in which the practice 
of anal sex involves feelings of trust, intimacy, etc. HIV testing is positioned as a crucial resource for establishing an agreement among the couple, that through testing could make a safer decision to abandon condom use. ${ }^{20}$

As observed in ethnographies of testing services in Brazil (MORA et al., 2014; BIEHL, 2007), the adoption of alterative means to constant condom use as part of initiatives to protect patients has turned into a strategy recognized by the biomedical and behavioral discourse. We are referring here to testing among partners as a way to abolish condom use. ${ }^{21}$

Another aspect that is surreptitiously evoked in the literature analyzed is the association between the use of sex and relationship apps and higher risk for acquiring HIV. Some studies propose subsidies for planning prevention actions among MSM who use apps as they are considered as more exposed to infection. In the rhetoric used, an "unprotected sexual practice" is associated with internet use in a discursive amalgam that includes the possibility of meeting various sexual partners, the use of alcohol and drugs, and optimism regarding ARVs. ${ }^{22}$ The particularities of risks described include a link between unprotected anal sex and higher probability of sex with people who are seropositive, sex under the influence of drugs, finding partners on the internet and having a primary partner. ${ }^{23}$ In the literature from the United States, for example, racialized categories prevail to delineate subgroups of MSM with higher exposure to HIV, such as "African-American MSM" and "Latin MSM", that are associated with risk factors such as use of injectable drugs and bisexual sexual practices. ${ }^{24}$

The way in which specialists comprehend the relationship between sexual risk and the use of apps stands out in the literature. The articles appear to maximize the moral weight of sexual encounters denominated as "occasional", as opposed to steady relationships. This is intensified even more when these relationships are mediated by technologies, as we identified in the studies that conduct mappings of sexual and social networks of telephone app users. One of the articles reviewed, for example, presents a map of these networks with the aim of identifying geographic areas with the largest concentration of black and Latino MSMs in Atlanta (USA). 25 The authors affirm that the app attracts people more exposed to sexual risks, and as such, that the socio-affective dynamics registered in these technologies can assist testing interventions in determinant geographical areas. On the other hand, a French study of knowledge and access to the self-test among men who use gay 
websites proposes a certain homogeneity among those who use the web to find partners and those that benefit from a health intervention via the internet. ${ }^{26}$

Testing recruitment strategies in the context of hook-ups (clubs, saunas, apps) correspond to determinate premise of specialists regarding the unequivocal relationship between risk and casual sex. The articles do not argue why the risks associated with relationship apps use would be exclusive to homosexuals. Nor why these risks would be distinct from "occasional hook-ups" that are not arranged through communication technologies. Such biomedical strategies suggest a continued focus on sexualities held as 'deviant', as discussed by Pelúcio and Miskolci (2009) in terms of prevention discourses.

Similar to the use of the category MSM, the meaning of "occasional partners" is hardly explicit in the literature. It can mean everything from one sexual relation with an unknown partner to sporadic sex with someone without an affective tie, to inconsistent condom use with a casual partner. Based on the literature analyzed, the only exception was a survey conducted in the United States with the objective of identifying concrete scenarios for exposure to HIV infection. The study explored the nuances of different forms of relationships between MSM, the places where they met their sexual partners and if they had a history of sex with people who were seropositive. ${ }^{27}$

It is important to highlight how these new HIV prevention strategies enter into the intimate scenario of couples and contexts of homosexual sociability. The introduction of the rapid test and the oral fluid fest, especially for home use, inaugurate new possibilities for biomedical intervention in contexts of sexual interaction. The symbolic consequences and practices of these tests deserve close attention. If before prevention prescriptions materialized with the presence of condoms, now laboratory tests are the new technologies in the couple's room or public spaces of sexual interaction. It's no longer a presumed serostatus, but that which is identified and demonstrated that takes the stage. In the literature reviewed, few studies pay attention to the social effects of the introduction of these innovations. We cite one of them. The research describes how young gays that received oral test kits for daily use reported on their initiative to do the test with sexual partners, sometimes on the first date. The situations in which there was a positive diagnosis of one of the sexual partners provoked less of a preventive effect than an interruption in the sexual 
routine and reorganization of the relationship, as such situations required mutual support among the people involved. ${ }^{28}$

The promotion of these tests with a focus on individuals denominated as MSM and the stimulus of their use in daily sexual interactions doesn't just extend the biomedical intervention to a particular modality of sexuality, as it also generates new sexual scripts (GAGNON, 2006).

In summary, as signaled by Knight et al. (2016), the current intensification of offering voluntary counseling and testing and routine testing could inform dominant representations of the relationship between homosexuality and AIDS. It is important, therefore, to question how much a diagnosis molded on liberalindividualistic principles, dissociated from the structural factors responsible for the origin and maintenance of AIDS stigma, could intensify stigmas in detriment of the benefits of a timely diagnosis.

\section{Final Considerations}

The literature review attests to the differentiated nature of the interventions offered with a focus on MSM that involve routine testing, as well as its incorporation into sexual-affective negotiations through self-diagnosis technologies, among others. An exploratory review the studies focused on sex workers and the trans population provided a comparative dimension to our hypothesis and raised questions regarding the large investments in the population referred to as MSM. Our analysis of the literature suggests that the majority of studies about these technologies' efficacy and the arguments to justify their use come from research conducted in the male homosexual universe. In populations considered priorities in current prevention policies, like female sex workers, these types of studies and analyses are practically inexistent.

The argument that the focus on MSM is justified due to anal sex being typical and more frequent in this group also deserves to be questioned. The articles reviewed about testing rarely take sexual practices as an object of their analysis. In general terms, we found that sexuality has received tangential attention in the current biomedical prevention approaches. Topics such as identity, practices and experiences of discrimination are rarely objects of empirical analysis in the literature about testing. These topics only come into play in arguments to justify choosing the 
population, a way to access them or an explication of the epidemiological frame. Even in the surveys in which researchers seek to assess sexual practices, it is worth questioning why anal sexual practices are approached as being exclusive to MSM when sociological studies have highlighted the importance of understanding the contexts of this practice in the heterosexual universe (GAGNON, 2006).

The analysis of the selected literature sought to understand the moralities actioned by specialists and their understandings about the sexuality of the intervention target groups. Arguments about new prevention strategies based on the test and treat pair oscillate between the naturalization of identity categories and the diversification of continuous surveillance practices of one's serological state (whose imperative character is hardly problematized).

The moralities implicit in arguments about testing recruitment strategies point to aspects that deserve close accompaniment, especially due to their unintended consequences. On the one hand, the specialized scientific discourse reveals meanings about male homosexuality that can be stereotypical at times, or only attentive to the overlaps between stigmas related to AIDS and sexuality when they are about barriers to test access. Namely, stigma related to sexual orientation and gender identity is evoked as one of the barriers to accessing testing and to justify the pertinence of testing services focused on MSM. On the other hand, while arguments that the use of apps for sexual encounters is a risk factor gain prominence in recent biomedical articles about prevention, hypotheses about the relationship between commercial heterosexual sex and technology use and its prevention implications continue to be absent.

It is necessary to consider how the MSM category is defined to understand the sexual moralities at play. The use of this category in prevention discourses underpinning testing follow the path of the universalization of sexual experiences and identities. The fluidity or non-necessity of defining sexual identities and practices analyzed in other studies, especially among young people of both sexes, has not been considered; a division is insistently maintained - apparently impervious - between the homosexual and heterosexual universes (DOLAN, 2005; DIAMOND, 2003; PEDERSEN e KRISTIANSEN, 2008; MORA et al., 2014; MONTEIRO et al., 2013). Parker and Aggleton (2015), in particular, contribute to this discussion in their reflection about how distinct expressions of homosexuality 
(roles, identities, etc.) should be understood according to different social markers. They also emphasize the relevance of situating and contextualizing the categories mobilized in research, be they behavioral or identity related: "Any uncritical extension of categories such as MSM and increasingly transgender in AIDS discourse ignores the importance of differences in sexual culture and sexual practice, and conflates identities and practices, as well as sexuality and gender, through a series of unexamined assumptions" (p. 1.554).

The way in which testing focused on MSM is presented seems to depart from an assumption that it is strengthening a consolidated public health strategy. This occurs despite the debates starting in 2000 regarding the loosening of testing guidelines, such as counseling and informed consent, as part of its expansion (MORA et al., 2014). In other words, distinct from the controversies arising from other prevention technologies (CAMARGO et al., 2013; MONTGOMERY, 2012; STRADLER et al., 2015), the focalized offer of testing is put in a context of strengthening and continuing prevention actions. In the name of the benefits of timely testing, however, there is little questioning of people's reasons for not being tested and the loss of the protagonist role present in condom use and counseling prevention approaches.

The expansion of testing is aligned with processes denominated as biomedicalization (CLARKE et al., 2003). The mercantilization of the body and its fluids are highlighted in this scenario, as is the very close relationship between the interests of biotechnology companies and public policy development. In addition, as discussed by Monteiro et al. (2017), in our analysis of the literature we found that the participation of NGOs in this context is also limited.

We identified a relevant characteristic within this arena of technological innovations and their implicit assumptions that is also discussed by Camargo et al. (2013). The studies appear to assume that sexual practices are rigid, and as such, tangential to prevention logics, while the adoption of testing routines appears as more "moldable" and effective for prevention strategies. The recent specialized scientific discourse reveals a tacit understanding that the effective control of the epidemic will not be achieved through attempts to introduce socio-behavioral changes into the arena of sexuality. Expectations are projected in the identification and treatment of the largest contingent possible of infected people, considering evidence that an undetectable viral load annuls the possibility of sexual transmission. According to 
this logic, a change in sexuality isn't at the center of the intervention, but rather the awareness of one's serological status in exercising their sexuality. In the case of MSM, they also bet on the routine offering of testing (and the adoption of prophylaxis medications before and after sex) as a means through which people could have greater self-control and improve their self-care.

Given our findings, it is crucial to reflect on the place, and possible symbolisms, of sexuality in the context of offering the test. In his discussion of the emergence of new discursive and disciplinary modalities surrounding sexuality, CARRARA (2015) affirms: "now any regulation can only be completely justified in the name of the preservation or promotion of the citizenship and health (physical or mental) of the individuals who are involved or implicated. It is "irresponsible" sexuality that should be inhibited or combated" (p.331).

After four decades, and following Carrara's thesis regarding shifts in how sexuality is deployed (2015), it is important to be attentive to the emergence of new moralities stemming from the notion of "sexual rights". Meaning the 'non consensual' and 'irresponsible' practices that are at the core of 'bad sex' (RUBIN, 1998), in addition to specific expressions of gender and sexual orientations. In this way, the strategies discussed in the literature have made the homosexual population more than visible: interconnections between diagnostic technologies and sexual, affective and social practices have emerged. Current efforts are concentrated in promoting the selfsurveillance of one's serological status in which the recognition of a new class of rights (medical prevention) and the surveillance of dangerous sex (serodiscordant) converge. The social history of AIDS is marked by a singular dynamic of tensions that arise from the predominance of medical and behavioral knowledge alongside to the construction of responses nourished by diverse knowledges (political, religious), social agents (professionals, activists, scientists), and the protagonist role of community movements (NGUYEN et al., 2011; EPSTEIN, 1996). Currently, the homogenization of male homosexual expressions seems to reinforce discourses that ignore the historical processes of critical participation and local expertise in the construction of responses to the epidemic (AGGLETON; PARKER, 2015). As such, it is fundamental that the current proposal for a new prevention paradigm be analyzed and discussed with all of the agents involved, especially in terms of their social consequences, symbolisms, and categorizations. ${ }^{29}$ 


\section{References}

AGGLETON, P.; PARKER, R. Moving Beyond Biomedicalization in the HIV Response: Implications for Community Involvement and Community Leadership Among Men Who Have Sex with Men and Transgender People. Am J Pub Health, v. 105, n. 8, p. 1.552-1.558, 2015.

AYRES, R. et al. Risco, vulnerabilidade e práticas de prevenção e promoção da saúde. In: SOUSA, G.; MINAYO, C.; AKERMAN, M. (Org.) Tratado de Saúde Coletiva. São Paulo: Editora Hucitec, 2007.

BEATTIE, T. S. H. et al. Personal, interpersonal and structural challenges to accessing HIV testing, treatment and care services among female sex workers, men who have sex with men and transgenders in Karnataka state, South India. J Epidemiol Community Health. London, 66, suppl 2, p. ii42-48, Oct. 2012.

BENZAKEN, A. et al. Intervenção de base comunitária para a prevenção das DST/Aids na região amazônica, Brasil. Rev Saúde Pública, v. 41, supl. 2, p. 118-26, 2007.

BIEHL, J. Will to live. New Jersey: Princeton University Press, 2007.

BOELLSTORFF, T. But do not identify as gay: A Proleptic Genealogy of the MSM Category. Cultural Anthropology, v. 26, p. 287-312, 2011.

CAMARGO JR., K. R. et al. Male circumcision and HIV: A controversy study on facts and values. Global Public Health: An International Journal for Research, Policy and Practice. 2013. DOI: $10.1080 / 17441692.2013 .817599$.

CARRARA, S. Moralidades, racionalidades e políticas sexuais no Brasil contemporâneo. Mana. Rio de Janeiro, v. 21, n. 2, p. 323-345, ago. 2015.

CLARKE, A. et al. Biomedicalization: Technoscientific Transformations of Health, Illness, and US Biomedicine. American Sociological Review, v. 68, p. 161-194, 2003.

DAVIS, M. Sex, Technology and Public Health. London: Palgrave Macmillan UK, 2009.

DEERING, K. N. et al. Successes and gaps in uptake of regular, voluntary HIV testing for hidden street- and off-street sex workers in Vancouver, Canada. AIDS Care, v. 27, n. 4, p. 499506, 2015.

DIAMOND, L. M. Was it a phase? Young women's relinquishment of lesbian/bisexual identities over a 5-year period. Journal of Personality and Social Psychology, v. 84, n. 2, p. 352-64, 2003.

DOLAN, K. Lesbian Women and Sexual Health: The Social Construction of Risk and Susceptibility. New York: Haworth Press, 2005.

EPSTEIN, S. Impure Science: AIDS, Activism, and the Politics of Knowledge. Berkeley: University of California Press, 1996. 
FOLLER, M. L.; MONTEIRO, S. The fluidity of sexual preference and identity: A challenge for social movements and AIDS prevention programs in Brazil. In: LUNDGREN, S.; MACHADO-BORGES, T.; WIDMARK, C. (Eds.). Bodies and Borders in Latin America. Stockholm: Stockholms Universitet, 2012.

FOLCH, C. et al. Incremento en la prevalencia del VIH y en las conductas de riesgo asociadas en hombres que tienen sexo con hombres: 12 años de encuestas de vigilancia en Cataluña. Gaceta Sanitaria, v. 24, n. 1, p. 40-46, 2010.

FONNER, V. A. et al. Voluntary counseling and testing (VCT) for changing HIV-related risk behavior in developing countries. Cochrane Database of Systematic Reviews, issue 9, 2012.

FORD, C. L. Usage of "MSM" and "WSW" and the broader context of public health research. American Journal of Public Health, v. 96, n. 1, p. 9, 2006.

FRY, P. Da hierarquia à igualdade: a construção histórica da homossexualidade no Brasil. In: . Para inglês ver. Identidade e política na cultura brasileira. Rio de Janeiro: Zahar, 1982.

GAGNON, J. O uso explícito e implícito da perspectiva da roteirização nas pesquisas sobre a sexualidade. In: . Uma interpretação do desejo. Rio de Janeiro: Relumé Dumará, 2006.

HEILBORN, M. L. Ser ou estar homossexual: dilemas de construção da identidade social. In: PARKER, R.; BARBOSA, R. (Orgs.). Sexualidades Brasileiras. Rio de Janeiro: Relume Dumará, 1996, p. 136-145.

- Dois é par: gênero e identidade sexual em contexto igualitário. Rio de Janeiro: Garamond, 2004.

KERRIGAN, D. et al. Community development and HIV/STI-related vulnerability among female sex workers in Rio de Janeiro, Brazil. Health Education Research, v. 23, p. 137, 2008.

KIPPAX, S. et al. Between individual agency and structure in HIV prevention: understanding the middle ground of social practice. Am J Public Health, v. 103, n. 8, p. 1.367-1.375, 2013.

KNAUTH, D. O vírus procurado e o vírus adquirido. Revista Estudos Feministas. UFSC, Florianópolis, v. 5, n. 2, p. 291-300, 1997.

KNIGHT, R.; SMALL, W.; SHOVELLER, J. A. HIV stigma and the experiences of young men with voluntary and routine HIV testing. Sociology of Health and Illness, v. 38, n. 1, p. 15367, jan. 2016.

LIPPMAN, S. A. et al. Social-environmental factors and protective sexual behavior among sex workers: the Encontros intervention in Brazil. Am J Public Health, v. 100, supl. 1, p. S216$223,2010$.

MONTEIRO, S. et al. Desafios do tratamento como prevenção do HIV no Brasil: Uma análise a partir da literatura sobre testagem. Cien Saúde Colet. Rio de Janeiro, set. 2017. 
MONTEIRO, S. et al. Sexual Diversity and Vulnerability to AIDS: the Role of Sexual Identity and Gender in the Perception of Risk by Young People (Rio de Janeiro, Brazil). Sexuality Research \& Social Policy, v. 7, p. 270-282, 2010.

MONTEIRO, S. et al. A produção acadêmica recente sobre estigma, discriminação, saúde e Aids no Brasil. In: MONTEIRO, S.; VILLELA, W. (Org.). Estigma e Saúde. Rio de Janeiro: Fiocruz, 2013, p. 1-207, v. 1.

MONTGOMERY, C. M. Making prevention public: The co-production of gender and technology in HIV prevention research. Social Studies of Science, v. 42, n. 6, p. 922-944, 2012. MORA, C.; MONTEIRO, S.; MOREIRA, C. O. Ampliación de las estrategias de consejería y prueba del VIH: desafíos técnicos y tensiones ético-políticas. Salud Colectiva, v. 10, p. 253-264, 2014.

MORRIS, S. R.; LITTLE, S. J. MSM: resurgent epidemics. Current opinion in HIV and AIDS. V. 6, n. 4, p. 326-32, July 2014.

NGUYEN, V-K. et al. Remedicalizing an epidemic: from HIV treatment as prevention to HIV treatment is prevention. AIDS, v. 25, p. 291-293, 2011.

PAI, M. et al. Systematic reviews and meta-analyses: An illustrated, step-by-step guide. The national medical journal of India, v. 17, n. 2, p. 86-95, 2004.

PARKER, R. I.; AGGLETON, P.; PEREZ-BRUMER, A. G. The trouble with 'Categories': Rethinking men who have sex with men, transgender and their equivalents in HIV prevention and health promotion. Global Public Health, v. 11, n. 7-8, p. 819-823, 2016.

PAWA, D. et al. Reducing HIV risk among transgender women in Thailand: a quasiexperimental evaluation of the sisters program. PLoS One. United States, v. 8, n. 10, p. e77-113, 2013.

PECHENY, M. HSH en América Latina: Itinerario de una categoría, persistencia de una epidemia, malestares en las respuestas. In: REDE SAGAS BRASIL. Interaçóes preventivas com juventudes homossexuais, mulheres lésbicas e pessoas vivendo com HIVIAIDS. Fortaleza: GRAB, 2012.

PEDERSEN, W.; KRISTIANSEN, H. W. Homosexual experience, desire and identity among young adults. Journal of Homosexuality, v. 54, n. 1-2, p. 68-102, 2008.

PELÚCIO, L.; MISKOLCI, R. A prevenção do desvio: o dispositivo da aids e a repatologização das sexualidades dissidentes. Sexualidad, Salud y Sociedad - Revista Latinoamericana, n. 1, p. 25-157, 2009.

ROMANO, V.F. As travestis no Programa Saúde da Família da Lapa. Saúde Soc., v. 17, n. 2, p. 211-9, 2008.

RUBIN, G. Thinking Sex: notes for a radical theory of the politics of sexuality. In: NARDI, 
P. M.; SCHNEIDER, B. E. (Eds.). Social perspectives in lesbian and gay studies: a reader. New York: Routledge, 1998.

SEGURADO, A. A. C. Prevenção biomédica da infecção por HIV/AIDS. In: PAIVA, V.; CALAZANS, G.; SEGURADO, A. (Orgs.). Vulnerabilidade e Direitos Humanos. Prevenção e promoção da saúde. Livro II. São Paulo: Juruá, 2013.

STADLER, J. et al. Adherence and the Lie in a HIV Prevention Clinical Trial. Medical Anthropology, v. 17, p. 1-14, Nov. 2015. [Epub ahead of print] <http://dx.doi.org/10.1080/0145 9740.2015.1116528>.

TREICHLER, P. AIDS, homophobia and biomedical discourse: An epidemic of signification. Cultural Studies, v. 1, n. 3, p. 263-305, 1987.

UNAIDS. The GAP report. Unaids, 2016. .90-90-90. An ambitious treatment target to help end the AIDS epidemic. Unaids, 2014.

YOUNG, R. M.; MEYER, I. H. The trouble with "MSM" and "WSW": erasure of the sexual minority person in public health discourse. A J Public Health, v. 95, n. 1.144-1.149, 2005.

WORLD HEALTH ORGANIZATION. Consolidated guidelines on HIV prevention, diagnosis, treatment and care for key populations. Geneva: WHO, 2014. 


\section{Notas}

${ }^{1}$ To differentiate the primary and secondary sources, we adopted a model in which the bibliographic references that make up the corpus analyzed are indicated by footnotes (the 65 references listed in Table 1). The rest of the references are cited in parentheses throughout the text, and consequently, listed in the Reference section.

${ }^{2}$ Cf. MACKELLAR et al., 2011.

${ }^{3}$ Cf. MANSERGH et al., 2006.

${ }^{4}$ Cf. BAVINTON et al., 2013; BAYTOP et al., 2014; BILARDI et al., 2013; DELANEY et al., 2014; FRASCA et al., 2014; GUMY et al., 2012; MARTINEZ et al., 2014; MITCHELL et al., 2014; O’BYRNE et al., 2014; PRESTAGE et al., 2008; PROST et al., 2007; PURCELL et al., 2014.

${ }^{5}$ Cf. FERNÁNDEZ-BALBUENA et al., 2014; BAYTOP et al., 2014.

${ }^{6}$ Cf. HOYOS et al., 2013a.

${ }^{7}$ Cf. FIRESTONE et al., 2014; IFEKANDU et al., 2014; ARNOLD et al., 2014.

${ }^{8}$ Cf., for example, FIRESTONE et al., 2014.

${ }^{9}$ Cf., for example, MACKELLAR et al., 2011.

${ }^{10}$ Cf., for example, BAVINTON et al., 2013.

${ }^{11}$ Cf. FAN, 2014.

${ }^{12}$ Cf., for example, FAIRLEY et al., 2014.

${ }^{13}$ Cf. MORRIS; LITTLE, 2014; FUQUA et al., 2012.

${ }^{14}$ Cf. DEERING et al., 2015.

${ }^{15}$ Cf. BENZAKEN et al., 2007.

${ }^{16}$ Cf. LIPPMAN et al., 2010; KERRIGAN et al., 2008.

${ }^{17}$ Cf. ROMANO, 2008; PAWA et al., 2013; BEATTIE et al., 2012.

${ }^{18}$ Cf. DELANEY et al., 2014; GOLDENBERG et al., 2014; AGARWAL et al., 2015.

${ }^{19}$ Cf., for example, FRASCA et al., 2014; MARTÍNEZ et al., 2014; GREACEN et al., 2012; LIPPMAN et al., 2014; MACKELLAR et al., 2011.

${ }^{20}$ Cf. MITCHELL, 2014; BAVINTON et al., 2013.

${ }^{21} \mathrm{Cf}$., for example, MITCHELL, 2014.

${ }^{22}$ Cf., for example, FOLCH et al., 2010.

${ }^{23}$ Cf. MAYER et al., 2012.

${ }^{24}$ Cf. FUQUA et al., 2012; MARSH et al., 2010; MCCREE et al., 2013.

${ }^{25}$ Cf. DELANEY et al., 2014.

${ }^{26}$ Cf. GREACEN et al., 2012.

${ }^{27}$ Cf. MAYER et al., 2012.

${ }^{28}$ Cf. MARTÍNEZ et al., 2014.

${ }^{29} \mathrm{C}$. Mora and M. Brigeiro were responsible for the design of the systematic review, organization of the material, data analysis and writing the article. S. Monteiro coordinated the research, and was responsible for the design of the systematic review strategy, the discussion of the results, and writing and revising the article. 
Table 1. References analyzed $(n=65)$

\begin{tabular}{|c|c|}
\hline 1 & $\begin{array}{l}\text { AGARWAL, A. et al. Implementation of a confidential helpline for men having sex } \\
\text { with men in India. JMIR mHealth uHealth, v. 3, n. 1, p. e17, } 2015 .\end{array}$ \\
\hline 2 & $\begin{array}{l}\text { BAI, X. et al. HIV prevalence and high-risk sexual behaviours among MSM repeat } \\
\text { and first-time testers in China: implications for HIV prevention. J Int AIDS Soc., v. } \\
17 \text {, p. } 18848,2014 \text {. }\end{array}$ \\
\hline 3 & $\begin{array}{l}\text { BAVINTON, B. R. et al. Which gay men would increase their frequency of HIV } \\
\text { testing with home self-testing? AIDS Behav, v. 17, n. 6, p. 2084-92, } 2013 \text {. }\end{array}$ \\
\hline 4 & $\begin{array}{l}\text { BAYTOP, C. et al. Comparison of strategies to increase HIV testing among } \\
\text { African-American gay, bisexual, and other men who have sex with men in } \\
\text { Washington, DC. AIDS Care, v. 26, n. 5, p. 608-12, } 2014 .\end{array}$ \\
\hline 5 & $\begin{array}{l}\text { BEATTIE, T. S. H. et al. Personal, interpersonal and structural challenges to } \\
\text { accessing HIV testing, treatment and care services among female sex workers, } \\
\text { men who have sex with men and transgenders in Karnataka state, South India. J } \\
\text { Epidemiol Community Health, v. 66, supl. 2, p. ii42-8, } 2012 \text {. }\end{array}$ \\
\hline 6 & $\begin{array}{l}\text { BERNSTEIN, K. T. et al. Same-sex attraction disclosure to health care providers } \\
\text { among New York City men who have sex with men: implications for HIV testing } \\
\text { approaches. Arch Intern Med, v. 168, n. 13, p.1.458-64, } 2008 .\end{array}$ \\
\hline 7 & $\begin{array}{l}\text { BILARDI, J. E. et al. Gay and bisexual men's views on rapid self-testing for HIV. } \\
\text { AIDS Behav, v. 17, n. 6, p. } 2.093-9,2013 \text {. }\end{array}$ \\
\hline 8 & $\begin{array}{l}\text { BINGHAM, T. A. et al. HIV risk factors reported by two samples of male } \\
\text { bathhouse attendees in Los Angeles, California, 2001-2002. Sex Transm Dis, v. 35, } \\
\text { n. 6, p. 631-6, } 2008 \text {. }\end{array}$ \\
\hline 9 & $\begin{array}{l}\text { BLAS, M. M. et al. Motivating men who have sex with men to get tested for HIV } \\
\text { through the internet and mobile phones: a qualitative study. PLoS One, v. 8, n. 1, p. } \\
\text { e54012, } 2013 \text {. }\end{array}$ \\
\hline 10 & $\begin{array}{l}\text { BROOKMEYER, R. et al. Combination HIV prevention among MSM in South } \\
\text { Africa: results from agent-based modeling. PLoS One, v. 9, n. 11, p. e112668, } 2014 .\end{array}$ \\
\hline 11 & $\begin{array}{l}\text { CARNICER-PONT, D. et al. Use of new technologies to notify possible contagion } \\
\text { of sexually-transmitted infections among men. Gac Sanit, May-Jun } 2015 .\end{array}$ \\
\hline 12 & $\begin{array}{l}\text { CASTILLO, M. et al. Creating partnerships for HIV prevention among YMSM: } \\
\text { the Connect Protect(R) Project and House and Ball Community in Philadelphia.J } \\
\text { Prev Interv Community, v. 40, n. 2, p. } 165-75,2012 \text {. }\end{array}$ \\
\hline
\end{tabular}




\begin{tabular}{|c|c|}
\hline 13 & $\begin{array}{l}\text { CHAMPENOIS, K. et al. ANRS-COM'TEST: description of a community-based } \\
\text { HIV testing intervention in non-medical settings for men who have sex with men. } \\
B M J \text {, v. } 2 \text {, n. } 2 \text {, p. e } 000693,2012 \text {. }\end{array}$ \\
\hline 14 & $\begin{array}{l}\text { CINTA, F. et al. Incremento en la prevalencia del VIH y en las conductas de } \\
\text { riesgo asociadas en hombres que tienen sexo con hombres: } 12 \text { ańos de encuestas de } \\
\text { vigilancia conductual en Cataluña. Gac Sanit, v. } 24 \text {, n. 1, p. } 40-6,2010 \text {. }\end{array}$ \\
\hline 15 & $\begin{array}{l}\text { COHALL, A. et al. HIV testing preferences among young men of color who have } \\
\text { sex with men. Am J Public Health, v. 100, n. 10, p. 1961-6, } 2010 .\end{array}$ \\
\hline 16 & $\begin{array}{l}\text { DELANEY, K. P. et al. Using a geolocation social networking application to } \\
\text { calculate the population density of sex-seeking gay men for research and prevention } \\
\text { services. J Med Internet Res, v. 16, n. 11, p. e249, } 2014 \text {. }\end{array}$ \\
\hline 17 & $\begin{array}{l}\text { DEWSNAP, C. H.; McOWAN, A. A review of HIV point-of-care tests. Int J STD } \\
\text { AIDS, v. 17, n. 6, p. 357-9, } 2006 .\end{array}$ \\
\hline 18 & $\begin{array}{l}\text { DORELL, C. G. et al. Missed opportunities for HIV testing in health care settings } \\
\text { among young African American men who have sex with men: implications for the } \\
\text { HIV epidemic. AIDS Patient Care STDS, v. } 25 \text {, n. 11, p. 657-64, } 2011 \text {. }\end{array}$ \\
\hline 19 & $\begin{array}{l}\text { EL-BASSEL, N. et al. Couple-based HIV prevention in the United States: } \\
\text { advantages, gaps, and future directions. J Acquir Immune Defic Syndr. United } \\
\text { States, v. 55, supl 2, p. S98-101, } 2010 .\end{array}$ \\
\hline 20 & $\begin{array}{l}\text { ELLEN, J. M. et al. Recruitment approaches to identifying newly diagnosed HIV } \\
\text { infection among African American men who have sex with men. Int J STD AIDS, v. } \\
24 \text {, n. } 5 \text {, p. 335-9, } 2013 \text {. }\end{array}$ \\
\hline 21 & $\begin{array}{l}\text { FAIRLEY, C. K.; LAW, M.; CHEN, M. Y. Eradicating syphilis, hepatitis C and } \\
\text { HIV in MSM through frequent testing strategies. Curr Opin Infect Dis, v. 27, n. 1, } \\
\text { p. } 56-61,2014 .\end{array}$ \\
\hline 22 & $\begin{array}{l}\text { FAN, E. L. HIV testing as prevention among MSM in China: the business of } \\
\text { scaling-up. Glob Public Health, v. 9, n. 1-2, p. 85-97, } 2014 .\end{array}$ \\
\hline 23 & $\begin{array}{l}\text { FERNÁNDEZ-BALBUENA, S. et al. Highly visible street-based HIV rapid } \\
\text { testing: is it an attractive option for a previously untested population? A cross- } \\
\text { sectional study. Sex Transm Infect, v. 90, n. 2, p. 112-8, } 2014 \text {. }\end{array}$ \\
\hline 24 & $\begin{array}{l}\text { FIRESTONE, R. et al. Effectiveness of a combination prevention strategy for HIV } \\
\text { risk reduction with men who have sex with men in Central America: a mid-term } \\
\text { evaluation. BMC Public Health, v. 14, p. } 1.244,2014 \text {. }\end{array}$ \\
\hline
\end{tabular}




\begin{tabular}{|c|c|}
\hline 25 & $\begin{array}{l}\text { FLOWERS, P.; McDAID, L. M.; KNUSSEN, C. Exposure and impact of a mass } \\
\text { media campaign targeting sexual health amongst Scottish men who have sex with } \\
\text { men: an outcome evaluation. BMC Public Health, v. 13, p. } 737,2013 .\end{array}$ \\
\hline 26 & $\begin{array}{l}\text { FRASCA, T. et al. Attitude and behavior changes among gay and bisexual men } \\
\text { after use of rapid home HIV tests to screen sexual partners. AIDS Behav, v. 18, n. } 5 \text {, } \\
\text { p. } 950-7,2014 \text {. }\end{array}$ \\
\hline 27 & $\begin{array}{l}\text { FUQUA, V. et al. Using social networks to reach Black MSM for HIV testing and } \\
\text { linkage to care. AIDS Behav, v. 16, n. 2, p. 256-65, } 2012 \text {. }\end{array}$ \\
\hline 28 & $\begin{array}{l}\text { GILBERT, M. et al. Factors associated with intention to use internet-based testing } \\
\text { for sexually transmitted infections among men who have sex with men. J Med } \\
\text { Internet Res, v. } 15 \text {, n. 11, p. e254, } 2013 \text {. }\end{array}$ \\
\hline 29 & $\begin{array}{l}\text { GOLDEN, M. R. et al. Peer referral for HIV case-finding among men who have } \\
\text { sex with men. } A I D S \text {, v. } 20 \text {, n. } 15 \text {, p. } 1.961-8,2006 \text {. }\end{array}$ \\
\hline 30 & $\begin{array}{l}\text { GOLDENBERG, T. et al. Preferences for a Mobile HIV Prevention App for Men } \\
\text { Who Have Sex With Men. JMIR Health Health, v. 2, n. 4, p. e47, } 2014 .\end{array}$ \\
\hline 31 & $\begin{array}{l}\text { GREACEN, T. et al. Access to and use of unauthorised online HIV self-tests by } \\
\text { internet-using French-speaking men who have sex with men. Sex Transm Infect, v. } \\
88 \text {, n. } 5 \text {, p. } 368-74,2012 \text {. }\end{array}$ \\
\hline 32 & $\begin{array}{l}\text { GU, J.; LAU, JTF.; TSUI, H. Psychological factors in association with uptake of } \\
\text { voluntary counselling and testing for HIV among men who have sex with men in } \\
\text { Hong Kong. Public Health, v. } 125 \text {, n. } 5 \text {, p. } 275-82,2011 \text {. }\end{array}$ \\
\hline 33 & $\begin{array}{l}\text { GUMY, C. et al. Five-year monitoring of a gay-friendly voluntary counselling and } \\
\text { testing facility in Switzerland: who got tested and why? BMC Public Health, v. 12, } \\
\text { n. } 422,2012 \text {. }\end{array}$ \\
\hline 34 & $\begin{array}{l}\text { HALKITIS, P. N. et al. Evaluation of the relative effectiveness of three HIV testing } \\
\text { strategies targeting African American men who have sex with men (MSM) in New } \\
\text { York City. Ann Behav Med, v. 42, n. 3, p. 361-9, } 2011 .\end{array}$ \\
\hline 35 & $\begin{array}{l}\text { HAN, L. et al. HIV self-testing among online MSM in China: implications for } \\
\text { expanding HIV testing among key populations. J Acquir Immune Defic Syndr, v. 67, } \\
\text { n. } 2 \text {, p. } 216-21,2014 \text {. }\end{array}$ \\
\hline 36 & $\begin{array}{l}\text { HAO, C. et al. A randomized controlled trial to evaluate the relative efficacy of } \\
\text { enhanced versus standard voluntary counseling and testing on promoting condom } \\
\text { use among men who have sex with men in China. AIDS Behav, v. 16, n. } 5 \text {, p. 1.138- } \\
47,2012 \text {. }\end{array}$ \\
\hline
\end{tabular}




\begin{tabular}{|c|c|}
\hline 37 & $\begin{array}{l}\text { HONG, N. T. T. et al. Utilization of HIV voluntary counseling and testing in } \\
\text { Vietnam: an evaluation of } 5 \text { years of routine program data for national response. } \\
\text { AIDS Educ Prev, v. } 23 \text {, n. } 3 \text { supl, p. } 30-48,2011 .\end{array}$ \\
\hline 38 & $\begin{array}{l}\text { HOYOS, J. et al. Preferred HIV testing services and programme characteristics } \\
\text { among clients of a rapid HIV testing programme. BMC Public Health, v. 13, n. } \\
791,2013 \mathrm{a} .\end{array}$ \\
\hline 39 & $\begin{array}{l}\text { HOYOS, J. et al. Never tested for HIV in Latin-American migrants and Spaniards: } \\
\text { prevalence and perceived barriers. J Int AIDS Soc, v. 16, p. 18560, 2013b. }\end{array}$ \\
\hline 40 & $\begin{array}{l}\text { HU, Q. et al. Barriers to acceptance of provider-initiated testing and counseling } \\
\text { among men who have sex with men in Shenyang, China: a cross-sectional study. } \\
\text { Biomed Res Int, p. } 280969,2013 \text {. }\end{array}$ \\
\hline 41 & $\begin{array}{l}\text { HUEBNER, D. M. et al. Implementing bathhouse-based voluntary counselling and } \\
\text { testing has no adverse effect on bathhouse patronage among men who have sex with } \\
\text { men. Int J STD AIDS, v. } 23 \text {, n. 3, p. 182-4, } 2012 \text {. }\end{array}$ \\
\hline 42 & $\begin{array}{l}\text { HUEBNER, D. M. et al. Rapid vs. standard HIV testing in bathhouses: what is } \\
\text { gained and lost? AIDS Behav, v. 14, n. 3, p. } 688-96,2010 \text {. }\end{array}$ \\
\hline 43 & $\begin{array}{l}\text { IFEKANDU, C.; SULEIMAN, A.; ANIEKWE, O. The cost-effectiveness in the } \\
\text { use of HIV counselling and testing-mobile outreaches in reaching men who have } \\
\text { sex with men (MSM) in northern Nigeria. J Int AIDS Soc, v. 17, n. } 4 \text { supl 3, p. } \\
\text { 19610, } 2014 .\end{array}$ \\
\hline 44 & $\begin{array}{l}\text { LAPERRIÈRE, H. Evaluation of STD/HIV/AIDS peer-education and danger: a } \\
\text { local perspective. Ciênc Saúde Coletiva, v. 13, n. 6, p. 1.817-24, } 2006 .\end{array}$ \\
\hline 45 & $\begin{array}{l}\text { LIPPMAN, S. A. et al. Acceptability of self-conducted home-based HIV testing } \\
\text { among men who have sex with men in Brazil: data from an on-line survey. Cad } \\
\text { Saúde Pública, v. } 30, \text { n. } 4 \text {, p. } 724-34,2014 \text {. }\end{array}$ \\
\hline 46 & $\begin{array}{l}\text { MacKELLAR, D. A. et al. Reasons for not HIV testing, testing intentions, and } \\
\text { potential use of an over-the-counter rapid HIV test in an internet sample of men } \\
\text { who have sex with men who have never tested for HIV. Sex Transm Dis, v. 38, n. } 5 \text {, } \\
\text { p. } 419-28,2011 \text {. }\end{array}$ \\
\hline 47 & $\begin{array}{l}\text { MacKELLAR, D. A. et al. Unrecognized HIV infection, risk behaviors, and } \\
\text { perceptions of risk among young men who have sex with men: opportunities for } \\
\text { advancing HIV prevention in the third decade of HIV/AIDS. J Acquir Immune } \\
\text { Defic Syndr, v. 38, n. 5, p. 603-14, } 2005 \text {. }\end{array}$ \\
\hline
\end{tabular}




\begin{tabular}{|c|c|}
\hline 48 & $\begin{array}{l}\text { MacPHERSON, P. et al. Feasibility and acceptability of point of care HIV testing } \\
\text { in community outreach and GUM drop-in services in the North West of England: } \\
\text { a programmatic evaluation. BMC Public Health, v. 11, n. 419, } 2011 \text {. }\end{array}$ \\
\hline 49 & $\begin{array}{l}\text { MANSERGH, G. et al. Adaptation of Venue-Day-Time Sampling in Southeast Asia } \\
\text { to Access Men Who Have Sex with Men for HIV Assessment in Bangkok. Field } \\
\text { methods. Atlanta, v. } 18, \text { n. } 2 \text {, p. } 135-52,2006 .\end{array}$ \\
\hline 50 & $\begin{array}{l}\text { MARCUS, U. et al. Risk factors for HIV and STI diagnosis in a community-based } \\
\text { HIV/STI testing and counselling site for men having sex with men (MSM) in a } \\
\text { large German city in } 2011 \text { inverted question mark2012. BMC Infect Dis, v. 15, n. 1, } \\
\text { p. 14, Jan. } 2015 .\end{array}$ \\
\hline 51 & $\begin{array}{l}\text { MARGOLIS, A. D. et al. "Never testing for HIV" among men who have sex with } \\
\text { men recruited from a sexual networking website, United States. AIDS Behav, v. 16, } \\
\text { n. } 1 \text {, p. } 23-9,2012 \text {. }\end{array}$ \\
\hline 52 & $\begin{array}{l}\text { MARLEY, G. et al. Introducing rapid oral-fluid HIV testing among high risk } \\
\text { populations in Shandong, China: feasibility and challenges. BMC Public Health, v. } \\
\text { 14, n. } 422,2014 \text {. }\end{array}$ \\
\hline 53 & $\begin{array}{l}\text { MARSH, K. A. et al. Who chooses a rapid test for HIV in Los Angeles County, } \\
\text { California? Eval Health Prof, v. 33, n. 2, p. 177-96, } 2010 .\end{array}$ \\
\hline 54 & $\begin{array}{l}\text { MARTINEZ, O. et al. Anticipated and actual reactions to receiving HIV positive } \\
\text { results through self-testing among gay and bisexual men. AIDS Behav, v. 18, n. } 12 \text {, } \\
\text { p. } 2.485-95,2014 \text {. }\end{array}$ \\
\hline 55 & $\begin{array}{l}\text { MATTIOLI, S. et al. HIV test: which is your best? A National survey on testing } \\
\text { preferences among MSM in Italy. J Int AIDS Soc., v. 17, n. 4, supl 3, p. 1.959, } 2014 .\end{array}$ \\
\hline 56 & $\begin{array}{l}\text { MAYER, K. H. et al. Unprotected sex, underestimated risk, undiagnosed HIV and } \\
\text { sexually transmitted diseases among men who have sex with men accessing testing } \\
\text { services in a New England bathhouse. J Acquir Immune Defic Syndr, v. 59, n. 2, p. } \\
\text { 194-8, } 2012 \text {. }\end{array}$ \\
\hline 57 & $\begin{array}{l}\text { McCREE, D. H. et al. Lessons learned from use of social network strategy in HIV } \\
\text { testing programs targeting African American men who have sex with men. Am J } \\
\text { Public Health, v. } 103 \text {, n. } 10 \text {, p. } 1.851-6,2013 \text {. }\end{array}$ \\
\hline 58 & $\begin{array}{l}\text { MITCHELL, J. W. Gay male couples' attitudes toward using couples-based } \\
\text { voluntary HIV counseling and testing. Arch Sex Behav, v. 43, n. 1, p. 161-71, } 2014 .\end{array}$ \\
\hline
\end{tabular}




\begin{tabular}{|l|l|}
\hline 59 & $\begin{array}{l}\text { O'BYRNE, P. et al. Overview of a gay men's STI/HIV testing clinic in Ottawa: } \\
\text { clinical operations and outcomes. Can J Public Health, v. 105, n. 5, p. e389-94, } \\
2014 .\end{array}$ \\
\hline $\mathbf{6 0}$ & $\begin{array}{l}\text { O'BYRNE, P. et al. Overviewing a Nurse-Led, Community-Based HIV PEP } \\
\text { Program: Applying the Extant Literature in Frontline Practice. Public Health Nurs, } \\
\text { Apr. 2015. }\end{array}$ \\
\hline $\mathbf{6 1}$ & $\begin{array}{l}\text { PATTANASIN, S. et al. Loss to follow-up and bias assessment among a cohort of } \\
\text { Thai men who have sex with men in Bangkok, Thailand. Int J STD AIDS, March } \\
\text { 2015. }\end{array}$ \\
\hline $\mathbf{6 2}$ & $\begin{array}{l}\text { PRESTAGE, G. et al. Trends in HIV testing among homosexual and bisexual men } \\
\text { in eastern Australian states. Sex Health, v. 5, n. 2, p. 119-23, 2008. }\end{array}$ \\
\hline $\mathbf{6 3}$ & $\begin{array}{l}\text { PROST, A. et al. “There is such a thing as asking for trouble": taking rapid HIV } \\
\text { testing to gay venues is fraught with challenges. Sex Transm Infect, v. 83, n. 3, p. } \\
\text { 185-8, 2007. }\end{array}$ \\
\hline $\mathbf{6 4}$ & $\begin{array}{l}\text { PURCELL, D. W. et al. Incorporating couples-based approaches into HIV } \\
\text { prevention for gay and bisexual men: opportunities and challenges. Arch Sex Behav, } \\
\text { v. 43, n. 1, p. 35-46, 2014. }\end{array}$ \\
\hline $\mathbf{6 5}$ & $\begin{array}{l}\text { SILVA, S. M. et al. Redução de danos: estratégia de cuidado com populaçôes } \\
\text { vulneráveis na cidade de Santo André - SP. Saude soc, v. 18, supl. 2, p. 100-3, 2009. }\end{array}$ \\
\hline
\end{tabular}




\section{Resumo}

\section{A testagem do HIV entre "HSH": tecnologias de prevenção, moralidade sexual e autovigilância sorológica}

As diretrizes globais de prevenção da Aids têm priorizado a ampliação da testagem do HIV entre grupos mais expostos ao vírus, como os denominados homens que fazem sexo com homens (HSH). Com base em revisão sistemática da produção acadêmica (20052015) nas bases PubMed, Sociological Abstract e Lilacs, sobre testagem com gays e HSH e formas de captação para diagnóstico, este trabalho analisa as relações entre produção de estratégias de prevenção e moralidades sexuais. $\mathrm{O}$ exame dos 65 artigos revela os modos de identificação dos sujeitos-alvo das estratégias de captação e de responsabilização pela própria vigilância sorológica, incluindo a testagem de rotina. Os achados apontam ainda a diversificação de lugares para testagem. Os pressupostos implícitos sobre sexualidade e afetividade gay se exprimem através da ênfase das intervençóes nos espaços de sociabilidade e de sexo ocasional, particularmente quando facilitado pelo uso de aplicativos. Atentos à dimensão simbólica das novas estratégias e tecnologias de prevenção, argumentamos que a ampliação da testagem com foco nos "HSH" opera um deslocamento da intervenção sanitária. Se antes as medidas de controle da epidemia visavam intervir no exercício da sexualidade dos sujeitos, os esforços atuais se concentram em promover a autovigilância do estado sorológico.

Palavras-chave: "testagem"; "HIV"; "homossexualidade"; "risco"; "moralidades sexuais". 